employees of the competent national authorities, or persons acting on their behalf, and who do not limit their actions merely to the essentially secret (unofficially) investigation of a criminal case, but directly influence the subject in order to provoke him to commit a crime, which would not have been committed under other circumstances, in order to make it possible to identify the crime, that is, to obtain evidence of illegal behavior and initiate criminal proecution.

Based on the results of a critical comparison of the material procedural mechanism introduced in Ukraine for identifying and legal response to provocative actions of representatives of the authorities with the established practice of the European Court, a conclusion has been made about the existence of a number of gaps in the investigated mechanism of criminal law regulation.

Keywords: provocation, right to a fair trial, complicity in a crime, covert investigative (search) actions, control over commission of a crime.

DOI: 10.33766/2524-0323.92.104-120 УДК 343.35

\author{
А. А. Вознюк, \\ доктор юридичних наук, професор, \\ завідувач наукової лабораторії з проблем \\ протидії злочинності ННI № 1 \\ Національної академії внутрішніх справ \\ (м. Київ, Україна) \\ e-mail: vaa.999999@gmail.com \\ iDttps:/ / orcid.org/0000-0002-3352-5626
}

\title{
ДЕКЛАРУВАННЯ НЕДОСТОВІРНОЇ ІНФОРМАЩЇ ТА УМИСНЕ НЕПОДАННЯ ДЕКЛАРАЩЇ: НОВІ МОДЕЛІ ЗАБОРОННИХ КРИМІНАЛЬНО-ПРАВОВИХ НОРМ
}

У статті проаналізовано переваги та недоліки сучасних моделей підстав відповідальності за декларування недостовірної інформації та умисне неподання декларації кримінально-правової, адміністративно-правової та змішаної.

Зроблено висновок, що нові підстави відповідальності за декларування недостовірної інформації та неподання декларації, а також пропозиції щодо них, висловлені у відповідних законопроєктах, мають недоліки, пов'язані з наявністю підгрунтя для визнання неконституційними нових заборонних кримінально-правових норм, їх санкціями, формами вини, порогом кримінальної відповідальності за декларування недосто-вірної інформації, конструкцією "неподання декларації" тощо.

Сформульовано рекомендації для практики застосування ст. 366-2 та 366-3 Кримінального кодексу України, а також надано пропозищії щодо їх удосконалення.

Ключові слова: декларування недостовірної інформації; неподання декларації; декларація особи, уповноваженої на виконання функцій держави або місцевого самоврядування; декларація доходів; суб'єкт декларування; корупщія; неконституційність.

Постановка проблеми. 27 жовтня 2020 року відбувся потужний удар по механізму протидії корупції в Україні: Конституційний Суд України (далі - КСУ) прийняв рішення, яке призвело до часткової «паралізації» роботи НАЗК та «зни-

(C) Вознюк А. А., 2020 
щення» окремих інструментів електронного декларування. Рішення КСУ, зокрема, передбачало визнання такою, що не відповідає Конституції України (є неконституційною) ст. 366-1 КК України [1]. Такі дії єдиного органу конституційної юрисдикції в Україні були неоднозначно сприйняті представниками громадянського суспільства: одні підтримали позищію КСУ, а інші - визнали ії такою, що має суттєві недоліки.

Оприлюднення рішення КСУ від 27 жовтня 2020 року призвело до активізації законопроектної роботи, спрямованої на «реанімацію» відповідної статті КК. 3 метою створення нової заборонної кримінально-правової норми, присвяченої декларуванню недостовірної інформації та умисному неподанню декларації, у Верховній Раді України було зареєстровано низку законопроєктів: № 4301 від 02.11.2020 (I. Геращенко та ін.), № 4307 від 02.11.2020 (Ю. Тимошенко), № 4309 від 03.11.2020 (Д. Монастирський та ін.), № 4310 від 03.11.2020 (Д. Монастирський та ін.), № 4434 від 27.11.2020 (внесений Президентом України), № 4441 від 30.11.2020 (Д. Монастирський та ін.), № 4460-д від 03.12.2020 (Д. Монастирський та ін.).

Урешті-решт 4 грудня 2020 р. прийнято Закон «Про внесення змін до деяких законодавчих актів України щодо встановлення відповідальності за декларування недостовірної інформації та неподання суб'єктом декларування декларації особи, уповноваженої на виконання функцій держави або місцевого самоврядування», яким передбачається відновлення кримінальної відповідальності за декларування недостовірної інформації (ст. 366-2 КК України) та неподання суб'єктом декларування декларації особи, уповноваженої на виконання функцій держави або місцевого самоврядування (ст. 366-3 КК України).

Аналіз останніх досліджень і публікацій. Вагомим внеском у розроблення проблематики кримінальної відповідальності за декларування недостовірної інформації є дослідження О.О.Дудорова, Д. Г. Михайленка, А. В. Савченка, М. I. Хавронюка та інших вчених. Попри значимість результатів проведених досліджень, чимало важливих питань, пов'язаних із тлумаченням та застосуванням кримінально-правової заборони, передбаченої ст. 366-1 КК України, залишалося дискусійними, а окремі з них - не дослідженими. Тож зазначене, а також створення нових підстав кримінальної відповідальності за декларування недостовірної інформації й умисне неподання декларації обумовлюють необхідність подальших досліджень указаної проблематики.

Формулювання цілей. Метою статті є аналіз переваг та недоліків сучасних моделей підстав відповідальності за декларування недостовірної інформації та умисне неподання декларації. Такий крок дасть можливість сформулювати рекомендації для практики застосування цих норм, а також пропозищії щодо їх удосконалення.

Виклад основного матеріалу. Спосіб, у який відбувалася реанімація кримінально-правової заборони декларування недостовірної інформації та умисного неподання декларації, викликає певні зауваження. 3 огляду на те, що КСУ визнав ст. 366-1 КК України неконституційною, варто було білыш детально звернути увагу на ї̈ якість, проблеми, які виникали на практищі і врахувати зазначене в но- 
вих конструкціях заборонних норм. Однак цього не було зроблено, як і не створено групу з фахівців, які досліджували цю тематику і могли б розробити більш досконалу модель відповідальності за певні діяння. За таких обставин закладаються «вибухові міни», які можуть знову «спрацювати» по механізму протидії корупції в України.

3 іншого боку відновлення підстав відповідальності за неподання декларації та декларування недостовірної інформащії є важливим кроком на шляху протидії корупщії в Україні. А прийняття нових норм, які містять певні недоліки, не виключає можливості їх подальшого вдосконалення, зважаючи на активний процес реформування кримінального законодавства.

Відновлення кримінальної відповідальності за декларування недостовірної інформації та умисне неподання декларації супроводжувалося активізацією законотворчої роботи. Аналіз відповідних законопроєктів свідчить про те, що в більшості з них пропонуються незначні удосконалення окремих підстав відповідальності за вказані діяння (таб. 1)

Таблиця 1

Законопроєкти щодо встановлення відповідальності за декларування недостовірної інформації та неподання декларації

\begin{tabular}{|c|c|}
\hline Законопроєкт & Що змінюється \\
\hline $\begin{array}{c}\text { № } 4301 \text { від 02.11.2020 } \\
\text { (І. Геращенко та ін.) }\end{array}$ & $\begin{array}{l}\text { - назва і номер статті (ст. 366-2 «Ухилення від деклару- } \\
\text { вання достовірної інформації») }\end{array}$ \\
\hline $\begin{array}{l}\text { № } 4307 \text { від 02.11.2020 } \\
\text { (Ю. Тимошенко) }\end{array}$ & $\begin{array}{l}\text { - передбачається виведення суддів КСУ з числа суб'єктів } \\
\text { декларування, а відпоовідно, і суб'єктів кримінальної від- } \\
\text { повідальності за відповідне кримінальне правопору- } \\
\text { шення }\end{array}$ \\
\hline $\begin{array}{l}\text { № } 4309 \text { від 03.11.2020 } \\
\text { (Д. Монастирський та } \\
\text { ін.) }\end{array}$ & $\begin{array}{l}\text { - пропонується лише адміністративна відповідальність за } \\
\text { відповідні діяння }\end{array}$ \\
\hline $\begin{array}{l}\text { № } 4310 \text { від } 03.11 .2020 \\
\text { (Д. Монастирський } \\
\text { та ін.) }\end{array}$ & $\begin{array}{l}\text { - номер статті (пропонується 366-2); } \\
\text { - санкція (штраф був від } 2500 \text { до } 3000 \mathrm{HМДГ,} \mathrm{а} \mathrm{пропону-} \\
\text { ється від } 3 \text { 000до } 6000 \text { НМДГ; виключено позбавлення } \\
\text { волі до } 2 \text { р.) }\end{array}$ \\
\hline $\begin{array}{l}\text { № } 4441 \text { від } 30.11 .2020 \\
\text { (Д. Монастирський } \\
\text { та ін.) }\end{array}$ & $\begin{array}{l}\text { - з КК України виключається ст. 366-1; } \\
\text { - КК України доповнюється статтями 366-2 «Деклару- } \\
\text { вання недостовірної інформації» і 366-3 «неподання } \\
\text { суб'єктом декларування декларації особи, уповноваже- } \\
\text { ної на виконання функцій держави або місцевого само- } \\
\text { врядування»; } \\
\text { - пропонується змінити діяння з «подання суб'єктом де- } \\
\text { кларування завідомо недостовірних відомостей у декла- } \\
\text { рації...» на «умисне внесення суб'єктом декларування } \\
\text { завідомо недостовірних відомостей до декларації...»; }\end{array}$ \\
\hline
\end{tabular}




\begin{tabular}{|c|c|}
\hline & $\begin{array}{l}\text { - пропонується збілышити поріг відповідальності за за } \\
\text { ст. } 366-2 \text { КК України: якщо такі відомості відрізняються } \\
\text { від достовірних на суму від } 500 \text { до } 3000 \text { прожиткових мі- } \\
\text { німумів для працездатних осіб (ч.1); якщо такі відомості } \\
\text { відрізняються від достовірних на суму понад } 3000 \text { про- } \\
\text { житкових мінімумів для працездатних осіб (ч.2); } \\
\text { - санкція ст. 366-2 КК України (у санкції ч.1 не передба- } \\
\text { чено позбавлення волі до } 2 \text { р.; у санкції ч.2 збільшено ро- } \\
\text { змір штрафу - від } 3000 \text { до } 5000 \text { тисяч неоподатковува- } \\
\text { них мінімумів доходів громадян); } \\
\text { - санкція ст. } 366-3 \text { КК України (не передбачено позбав- } \\
\text { лення волі до } 2 \text { р.) }\end{array}$ \\
\hline $\begin{array}{l}\text { № } 4434 \text { від } 27.11 .2020 \\
\text { (внесений Президен- } \\
\text { том України) }\end{array}$ & 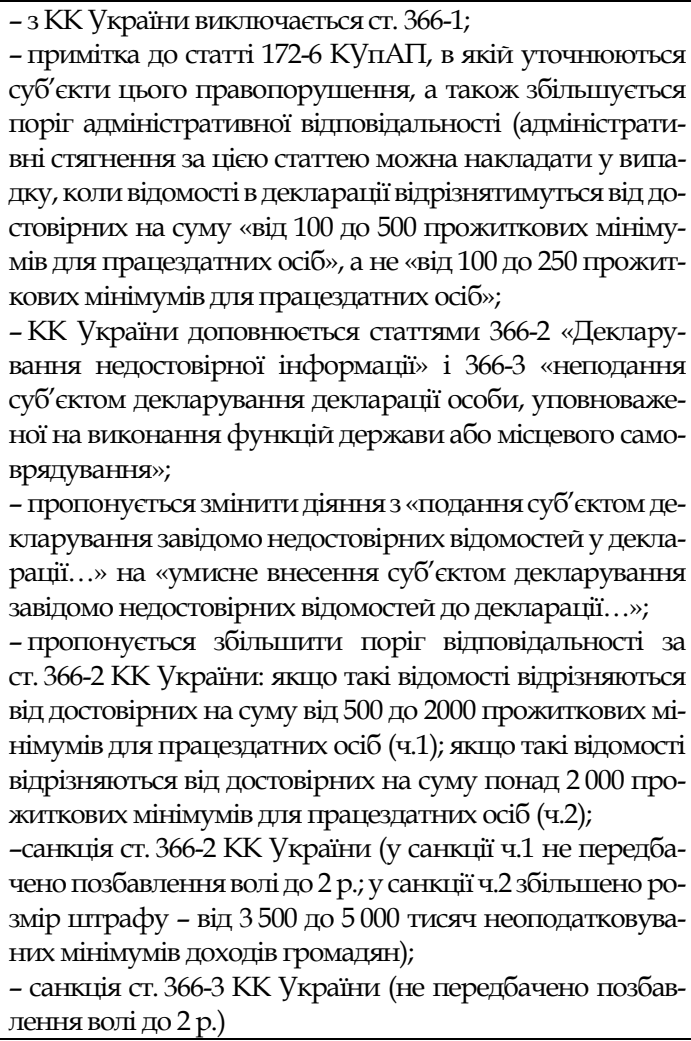 \\
\hline $\begin{array}{l}\text { № 4460-д від 03.12.2020 } \\
\text { (Д. Монастирський } \\
\text { та ін.) }\end{array}$ & $\begin{array}{l}\text { - з КК України виключається ст. 366-1; } \\
\text { - примітка до статті 172-6 КУпАП, у якій уточнюються } \\
\text { суб'єкти цього правопорушення, а також збільшується } \\
\text { поріг адміністративної відповідальності (адміністрати- }\end{array}$ \\
\hline
\end{tabular}




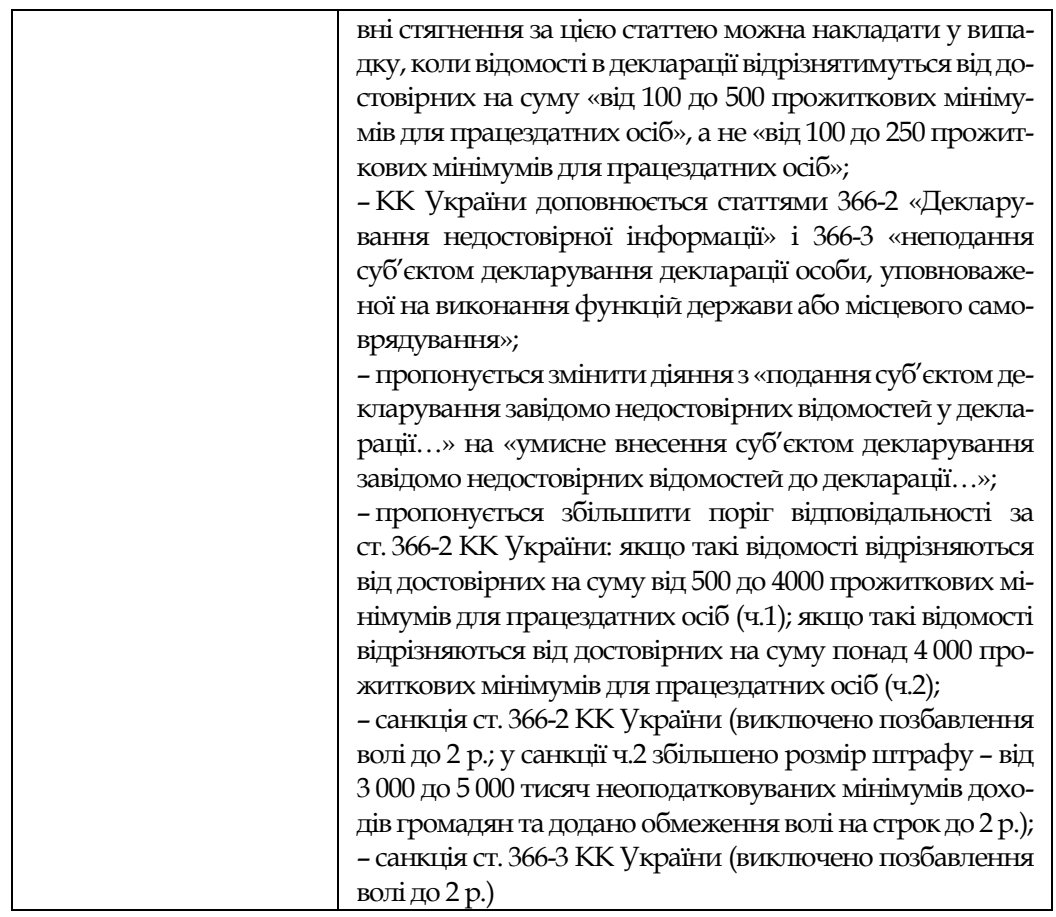

На основі аналізу положень цих законопроєктів, а також вивчення зарубіжного досвіду відповідальності за декларування недостовірної інформації та неподання декларації можна виокремити три моделі підстав такої відnовідальності: 1) кримінально-правову (передбачає встановлення кримінальної відповідальності за ці діяння); 2) адміністративно-правову (передбачає встановлення адміністративної відповідальності за ці діяння); 3) змішану (включає підстави різних видів відповідальності за ці діяння).

Ознайомлення з основними положеннями законопроєктів, що стосуються відповідальності за декларування недостовірної інформації та неподання декларації, свідчить про те, що окремі елементи запропонованих у них механізмів мають певні вади.

1. Залишається підгрунтя для визнання неконституційними нових заборонних кримінально-правових норм. У більшості законопроєктів пропонуються конструкції статті (статей), які максимально наближені, а в певних випадках тотожні ст. 366-1 КК України, яка була визнана неконституційною. Наприклад, законопроєкт № 4301 від 02.11.2020 (І. Геращенко та ін.) передбачав лише зміну назви і номеру статті (пропонується ст. 366-2 «Ухилення від декларування достовірної інформації»). Законопроєктом № 4307 від 02.11.2020 (Ю. Тимошенко) пропонувалося виве- 
дення суддів КСУ з ряду суб'єктів декларування, а відповідно, і суб'єктів кримінальної відповідальності за відповідне кримінальне правопорушення. Законопроєкт № 4310 від 03.11.2020 (Д. Монастирський та ін.) містив положення щодо зміни номера статті (пропонується 366-2) та санкції (штраф був від 2500 до 3000 НМДГ, а пропонується від 3000 до 6000 НМДГ; виключено позбавлення волі до 2 р.). У трьох законопроєктах (№ 4441 від 30.11.2020, № 4434 від 27.11.2020 та № 4460-д від 03.12.2020) пропонується встановити кримінальну відповідальність за ті ж самі діяння в різних статтях (ст. 366-2 та 366-3 КК України), збільшити поріг відповідальності за декларування недостовірної інформації та змінити санкції (збільшити розмір штрафу та виключити позбавлення волі). 3 огляду на такі незначні зміни, залишається підгрунтя для повторного визнання відповідної статті неконституційною. І це не дивно, оскільки в межах кримінально-правової моделі відповідальності за вказані діяння в зарубіжних країнах здебільшого криміналізовано лише неподання декларації та декларування недостовірної інформації. Відтак запропонувати кардинально інші інструменти для забезпечення механізму декларування особами, уповноваженими на виконання функцій держави або місцевого самоврядування неможливо. Можна лише перейти до іншої моделі, наприклад, адміністративно-правової.

2. Чи достатньо підстав адміністративної відповідальності за вказані діяння? Законопроєктом № 4309 від 03.11.2020 пропонувалася виключно адміністративна відповідальність за відповідні діяння у ст. 172-6 КУпАП (несвоєчасне подання без поважних причин декларації (ч.1); умисне неподання декларації (ч.6); подання завідомо недостовірних відомостей у декларації, якщо такі відомості відрізняються від достовірних на суму: від 100 до 250 прожиткових мінімумів для працездатних осіб (ч.4) та понад 250 прожиткових мінімумів для працездатних осіб (ч.6). По-перше, це не дає гарантій того, що КСУ в майбутньому не зможе визнати зазначену норму неконституційною. По-друге, чи зможуть за таких обставин правоохоронщі притягнути до відповідальності топкорупціонерів, адже зібрати докази їх протиправних діянь адміністративно-правовими засобами буде нелегко. По-третє, зарубіжний досвід свідчить про те, що за вказані діяння в одних країнах застосовують заходи адміністративно-правової (наприклад, Білорусія, Венесуела, Данія, Фінляндія), а в других - кримінальної відповідальності (наприклад, Чехія, Польща, Литва, Латвія, Болгарія, Молдова та Перу). Відтак, у кожній країні обирають ті правові інструменти забезпечення механізму декларування доходів та видатків, які вважають найбільш ефективними в межах своєї держави.

3. Чи варто із санкцій відповідних статей виключати покарання у вигляді позбавлення волі? У законопроєктах № 4310 від 03.11.2020, № 4441 від 30.11.2020, № 4434 від 27.11.2020, № 4460-д від 03.12.2020 із санкції нової заборонної кримінально-правової норми пропонується виключити таке покарання, як позбавлення волі на певний строк. Такий крок, очевидно, обумовлений необхідністю усунення зауважень, висловлених у рішенні КСУ про визнання ст. 366-1 КК України неконституційною. Однак, знову ж таки звертаю увагу на той факт, що зазначене рішення КСУ було необгрунтованим. На підтвердження своєї позищії наведу як аргумент хоча б той факт, що такі покарання існують у санкціях відповідних норм інших країн. 
Наприклад, у Болгарії такі дії караються позбавленням волі на строк до трьох років (ст. 313 КК Болгарії) [2], у Латвії - тимчасовим позбавленням волі або позбавленням волі на строк до двох років (ст. 219 КК Латвії) [3], у Чехії - позбавленням волі на строк від шести місяців до трьох років (§ 227 КК Чехії) [4], у Молдові - позбавленням волі на термін до 1 року (ст. 352-1 КК Молдови) [5], у Польщі - позбавленням волі від 6 місяців до 8 років (ч. 1 ст. 233 КК Польщі) [6], у Македонії - позбавленням волі від шести місяців до п'яти років (ч. 1 ст. 359-а КК Македонії) [7].

Закон про етику в уряді 1978 року та Закон про реформу етики 1989 року США передбачають суворі заходи покарання за порушення конфлікту інтересів та зловживання, пов'язані з власністю. Проти тих, хто навмисно надає неправдиву інформацію, порушується кримінальне провадження. Вони можуть бути засуджені до штрафу в розмірі до 250000 доларів США або 5 років позбавлення волі [8].

Варто також погодитися з Д. Г. Михайленком у тому, що встановлення достатньо жорстких покарань за декларування недостовірної інформації й відсутність законодавчих підстав для звільнення від кримінальної відповідальності, покарання і його відбування повною мірою відповідає критеріям ефективності правових норм для протидії корупційним правопорушенням [9].

4. Занадто Високим видається поріг кримінальної відповідальності. Кримінальна відповідальність за подання завідомо недостовірних відомостей до декларації раніше (у ст. 366-1 КК України) наставала, якщо такі відомості відрізнялися від достовірних на суму від 250 прожиткових мінімумів для працездатних осіб. Водночас, нині, відповідно до ст. 366-2 КК України, вони повинні відрізнятися на суму понад 500 прожиткових мінімумів для працездатних осіб. Таким чином, на сьогодні за брехню в декларації щодо квартири чи авто може наставати адміністративна відповідальність.

5. Нові кримінально-правові заборони не включено до переліку корупиійних кримінальних правопорушенъ. Цікавим є той факт, що Законом України «Про внесення змін до деяких законодавчих актів України щодо забезпечення ефективності інституційного механізму запобігання корупщії від 2 жовтня 2019 року примітку до статті 45 після цифр «365-2» доповнено цифрами «366-1» [10]. Відтак цей злочин було визнано корупщійним. Однак у примітці до ст. 45 КК України, що міститься на сайті Верховної Ради України (https://zakon.rada.gov.ua/laws), ст. 366-1 відсутня. Очевидно, що зазначені проблеми пов' язані виключно з низьким рівнем професіоналізму осіб, які відповідають за цей напрям законотворчої роботи.

Безумовно, декларування недостовірної інформації має певне відношення до корупції, оскільки в окремих випадках особи, які вчиняють корупційні кримінальні правопорушення, намагаються приховати незаконно здобуті кочти чи майно і вдаються, зокрема, до подання в декларації недостовірної інформації. Водночас, незаконно здобуте майно, яке приховує суб'єкт декларування, може бути отримане в результаті вчинення не лише корупційного, а й іншого адміністративного чи кримінального правопорушення.

Умисне неподання декларації та декларування недостовірної інформації це діяння, які не містять необхідних ознак корупщійного кримінального правопо- 
рушення, які, насамперед пов' язані з неправомірною вигодою та незаконним використанням влади, службового становища чи певних повноважень. Вивчення судової практики свідчить про те, що умисне неподання декларації, як правило, не має жодного зв'язку з іншими корупщійними кримінальними правопорушеннями. Аргументом на користь того, що нові заборонні кримінально-правові норми не варто відносити до корупщійних кримінальних правопорушень, видається, є той факт, що кримінально-правові наслідки за кримінальні корупщійні делікти, які передбачені в нормах інститутів звільнення від кримінальної відповідальності, призначення покарання, звільнення від покарання та його відбування, $є$ надто суворими для осіб, які не подали декларацію чи зазначили в ній недостовірні відомості.

Однак, очевидно, що варто говорити не лише про виключно корупційні кримінальні правопорушення, але й кримінальні правопорушення, пов'язані 3 корупцією, до яких доцільно відносити й умисне неподання декларації та декларування недостовірної інформації. До речі, злочин, передбачений ст. 366-1 КК України, неодноразово називали злочином, пов'язаним із корупцією [11, с. 187; 12 , с. $50 ; 13$, с. 238$]$.

Таким чином, відновлені підстави кримінальної відповідальності за декларування недостовірної інформації та неподання декларації у ст. 366-2 та 366-3 КК України максимально схожі до тих, що існували у ст. 366-1 КК України та яку визнали неконституційною. На перший погляд, зазначене свідчить про те, що існують передумови для визнання нових статей закону про кримінальну відповідальність неконституційними. Однак, якщо враховувати той факт, що рішення КСУ є необгрунтованим через брак необхідних аргументів [14], імовірно, таких незначних змін достатньо для відновлення підстав кримінальної відповідальності за ці діяння, однак таких змін недостатньо для підвищення ефективності застосування відповідних заборонних правових норм.

6. Чи обгрунтованим є Вживання терміна «завідомість» у ст. 366-2 КК України?

Найбільше труднощів під час розслідування цього злочину пов'язано із доказуванням умислу на подання недостовірної інформації до електронної декларації. Складнощі обумовлені тим, що суб'єкти декларування посилаються на різні обставини, що ставлять під сумнів наявність умисної форми вини, зокрема на такі: не володіння повною інформацією про активи членів сім'ї; використання помічників для заповнення декларації, які можуть щось переплутати або не вказати; недостатньо чіткі та зрозумілі законодавчі положення, що визначають особливості заповнення та подання електронної декларування; відповідні роз'яснення НАЗК тощо [15]. У випадку декларування недостовірної інформації не суб'єктом декларування, а на його прохання іншою особою склад кримінального правопорушення, передбаченого ст. 366-2 КК України, буде відсутній. Не слід виключати і можливої змови суб'єкта декларування зі своїм помічником щодо внесення ним недостовірної інформації. У такому випадку довести факт вчинення кримінального правопорушення буде дуже складно, а в певних випадках -практично неможливо. Як тоді бути, якщо в декларації наявні неправдиві відомості, однак від- 
сутня або недоведена умисна форма вини? Очевидно, що для таких ситуацій варто передбачити механізм внесення відповідних виправлень до вже поданої декларації.

Водночас виникає запитання, чи можлива необережна форма вини під час неподання декларації чи декларування недостовірної інформації? Якщо й так, то юридична відповідальність (кримінальна чи адміністративна) за ці діяння буде виключатися з огляду на те, що вони можуть вчинятися лише з умисною формою вини.

Серед дослідників висловлювалася пропозиція виключити слово «завідомо» 3 диспозищії ст. 366-1 КК України [16]. Термін «завідомо» означає наперед, заздалегідь, явно, свідомо [17]. У проєкті КК України 2020 р. вживається термін «завідомість» усвідомлення особою, яка вчиняє злочин, певного факту як явного, очевидного, такого, що не підлягає сумніву. «Завідомість» означає, що злочин вчинено з прямим умислом (п.10 ч.2 ст. 1.3.1. проєкту) [18]. Зважаючи на це, можна стверджувати, що в ст. 366-2 КК України «завідомо» означає, що особа вносить недостовірні відомості до декларації свідомо, заздалегідь усвідомлюючи їх неправдивий характер.

Видається зайвим одночасне застосування в конструкції діяння, передбаченого ст. 366-2 КК України термінів «умисно» та «завідомо», оскільки вони обидва вказують на умисну форму вини, зокрема термін «завідомо» - на прямий умисел. Окрім цього, імовірно, варто піти тим шляхом, яким рухалися законодавці в окремих зарубіжних країн, і вилучити з конструкцій відповідних діянь слова «умисно» та «завідомо» або диференціювати відповідальність за відповідні діяння залежно від форми вини в різних статтях, або в різних частинах однієї статті. За таких обставин кримінальна відповідальність за вказані діяння може наставати у випадку їх вчинення як умисно, так і необережно.

7. Які кримінально-правові наслідки буде мати подання декларації після початку кримінального провадження. Нові заборонні кримінально-правові норми не включені до переліку корупщійних кримінальних правопорушень. Кримінальні правопорушення, передбачені ч.1 ст. 366-2 та ст. 366-3 КК України, належать до кримінальних проступків, а кримінальне правопорушення, передбачене ч.2 ст. 366-2 КК України, - до нетяжких злочинів. Відтак на практищі подання особою декларації після початку кримінального провадження в певних випадках може оцінюватися як дійове каяття або зміна обстановки й особа буде звільнена від кримінальної відповідальності. Наприклад, у 2018 р. за декларування недостовірної інформації з 533 осіб від кримінальної відповідальності у зв'язку з дійовим каяттям звільнено 432 особи, тобто 81 \%, а у зв'язку зі зміною обстановки - 63 особи, тобто 11,8 \% [20]. Однак подання декларації після початку кримінального провадження не можна оцінювати як зміну обстановки. Не слід визнавати й дійовим каяттям подання декларації після затвердження обвинувального акта чи його надходження до суду. У зв' язку з цим, очевидно, слід чітко диференціювати пом' якшувальний ефект цієї обставини (подання декларації), залежно від часу вчинення відповідних дій. Вочевидь, не може бути дійового каяття в тих випадках, коли кримінальне правопорушення розкрито, а досудове розслідування завершено, оскільки відповідно до ст. 45 КК України таке каяття включає три обставини: 1) щире каяття; 2) активне сприяння розкриттю 
кримінального правопорушення; 3) повне відшкодування завданих збитків або усунення заподіяної шкоди. Активне сприяння розкриттю кримінального правопорушення можливе лише під час досудового розслідування, а не після нього [15, с. 112]. Однак подання декларації після затвердження обвинувального акта може бути визнано судом обставиною, що пом' якшує покарання.

Віднесення нових кримінально-правових заборон до категорії кримінальних проступків фактично сприяє уникненню винними кримінальної відповідальності, адже, відповідно до п.1 ч.1 ст. 49 КК України, такі суб'єкти декларування можуть бути звільнені від кримінальної відповідальності, якщо з дня вчинення ними кримінального правопорушення і до дня набрання вироком законної сили мине два роки.

Зазначене свідчить про те, що нові кримінально-правові заборони варто було б віднести хоча б до нетяжких злочинів.

8. Яким має бути період володіння чи користування об'єктом декларування щоб відображати иі факти В деклараціï? Серед законодавчих проблем варто виокремити положення ч.2 ст. 46 Закону України «Про запобігання корупщії, відповідно до якого дані про об'єкт декларування, що перебував у володінні або користуванні суб' єкта декларування або членів його сім'ї, зазначаються в декларації, якщо такий об'єкт перебував у володінні або користуванні станом на останній денъ звітного періоду або протягом не менше половини днів протягом звітного періоду.

Термін «не менше половини днів протягом звітного періоду» видається дещо необгрунтованим. Білыш логічною є позиція дослідників, які пропонують зменшити цей термін, наприклад до «не менше третини днів звітного періоду» [16, с. 4]. Звичайно, важко визначити ідеальний період володіння чи користування об' єктом декларування, який дає підстави вносити такі дані в декларацію, однак він не має бути занадто коротким чи занадто тривалим.

Водночас, абсолютно не можна погодитися із необхідністю внесення даних про об'єкт декларування, що перебував у користуванні суб'єкта декларування або членів його сім'ї, станом на останній день звітного періоду. Відтак, якщо, наприклад, суб'єкт декларування 31 грудня йде у відпустку і їде відпочивати до батьків, друзів, родичів, знайомих чи за кордон, користується чужим транспортним засобом, житлом - він зобов'язаний вносити цю інформацію до декларації. Однак коли ж це відбувається в будь-який інший день, декларувати об'єкти декларування немає необхідності, якщо вони, звісно, не перебувають у користуванні суб'єкта декларування або членів його сім'ї протягом не менше половини днів за звітний період. Це, дійсно, абсурд.

Така позищія законодавця є необгрунтованою. Щодо необхідності декларування володіння об'єктами декларування сумнівів жодних не виникає, однак стосовно до користування такими об'єктами, необхідні законодавчі зміни, оскільки в суб'єктів декларування 31 грудня існує вибір: не користуватися об'єктами, які необхідно декларувати, або ж навпаки, користуватися і декларувати. По суті, недекларування користування певним об'єктом лише одну добу - 31 грудня, з одного боку, є малозначним діянням, а з іншого - певним інструментом тиску на будьякого суб'єкта декларування, оскільки навряд чи особи, які святкували Новий рік 
не вдома, будуть декларувати місце святкування, хоча де-юре повинні. Так само навряд чи логічно декларувати чужий транспортний засіб, яким такі суб'єкти користувалися в цей день, хоча цього вимагає закон.

9. Особливої уваги в контексті удосконалення конструкцій відповідних заборонних норм потребує таке діяння, як НЕПодання декларації. Як варіант, можна запропонувати удосконалення існуючих підстав адміністративної та кримінальної відповідальності за ці діяння. Якщо особа умисно не подає декларацію у встановлений строк, то її слід повідомити про неподання нею декларації та надати певний термін для іï подання (наприклад 1 місяць 3 моменту повідомлення НАЗК). Після спливу зазначеного терміну, залежно від поведінки особи, ії слід притягнути до адміністративної відповідальності (у випадку якщо вона подала декларацію, однак, це подання визнається несвоєчасним і без поважних причин) або ж до кримінальної відповідальності (якщо вона навіть після зазначеного повідомлення НАЗК і додатково наданого строку не подала відповідну декларацію). Якщо в особи були поважні причини, то адміністративна та кримінальна відповідальність повинні виключатися за умови все ж подання декларації навіть після спливу обох строків. Якщо ж в особи не було поважних причин неподання декларації, однак вона подала їі після спливу другого строку, то особу все ж слід притягувати до кримінальної відповідальності, однак враховувати факт подання декларації як обставину, що пом' якшує покарання [19, с. 51]. Відтак, очевидно, слід удосконалити конструкщію умисного неподання декларації. До речі, у ст. 355 КК Грузії встановлено відповідальність за ненадання декларації про майновий стан, вчинене після накладання адміністративного стягнення за таке ж діяння [21]. Відповідно до § 227 КК Чехії, будь-яка особа, яка перебуває в судовому або іншому державному органі, буде нести кримінальну відповідальність, якщо вона відмовляється виконати юридичне зобов' язання щодо подання декларащії про майновий стан або уникає такого зобов' язання [4].

У таких випадках слід також передбачити обов' язкове звільнення з відповідної посади за неподання декларації.

Можливо, варто було створити єдину заборонну кримінально-правову норму, яка б стосувалася електронної декларації та відбиття в ній певної інформації, насамперед щодо активів. У відповідній об'єднаній заборонній кримінально-правовій нормі можна передбачити підстави кримінальної відповідальності за такі діяння: 1) недекларування необхідних відомостей, зокрема активів у певних розмірах; 2) декларування активів, джерело походження яких непояснене або неправдиве; 3) неподання декларації [19, с. 50-51].

Висновки. Підбиваючи підсумки здійсненого дослідження, слід сформулювати низку висновків.

1. Виокремлено три моделі підстав відповідальності за декларування недостовірної інформації та неподання декларації: 1) кримінально-правову (передбачає встановлення кримінальної відповідальності за ці діяння); 2) адміністративноправову (передбачає встановлення адміністративної відповідальності за ці діяння); 3) змішану (включає підстави різних видів відповідальності за ці діяння). 
2. Нові підстави відповідальності за декларування недостовірної інформації та неподання декларації, а також пропозиції щодо них, висловлені у відповідних законопроєктах, мають такі вади:

1) залишається підгрунтя для визнання неконституційними нових заборонних кримінально-правових норм (це пояснюється насамперед тим, що рішення КСУ щодо визнання ст. 366-1 КК України є необгрунтованим; у межах кримінально-правові моделі відповідальності за декларування недостовірної інформації не лише в Україні, але й в інших країнах, окрім криміналізації таких діянь, запропонувати кардинально інші інструменти для забезпечення механізму декларування неможливо);

2) підстав виключно адміністративної відповідальності за неподання декларації чи декларування недостовірної інформації, очевидно, недостатньо, оскільки притягнути до юридичної відповідальності топкорущціонерів, використовуючи лише адміністративно-правові засоби, в України нині досить складно;

3) не варто було із санкцій відповідних статей виключати покарання у вигляді позбавлення волі, що підтверджує досвід зарубіжних країн;

4) поріг кримінальної відповідальності за декларування недостовірної інформації є занадто високим, а тому його слід знизити;

5) кримінальні правопорушення, передбачені ст. 366-2, 366-3 КК України, не належать до корупційних, однак їх доцільно віднести до кримінальних правопорушень, пов' язаних із корупцією;

6) з огляду на відсутність в окремих випадках умисної форми вини подання недостовірних відомостей, варто передбачити для таких ситуацій механізм внесення відповідних виправлень до вже поданої декларації;

7) видається зайвим одночасне застосування в конструкції діяння, передбаченого ст. 366-2 КК України термінів «умисно» та «завідомо», оскільки вони обидва вказують на умисну форму вини, зокрема термін «завідомо» на прямий умисел;

8) з конструкцій відповідних діянь варто вилучити слова «умисно» та «завідомо» або диференціювати відповідальність за відповідні діяння залежно від форми вини в різних статтях, або в різних частинах однієї статті (за таких обставин кримінальна відповідальність за вказані діяння може наставати у випадку їх вчинення як умисно, так і необережно);

9) подання декларації після початку кримінального провадження не можна оцінювати як зміну обстановки; не слід визнавати й дійовим каяттям подання декларації після затвердження обвинувального акта чи його надходження до суду з огляду на те, що активне сприяння розкриттю кримінального правопорушення можливе лише під час досудового розслідування, а не після нього;

10) нові кримінально-правові заборони варто було б віднести хоча б до нетяжких злочинів;

11) необгрунтованим є положення ч. 2 ст. 46 Закону України «Про запобігання корупщіi» щодо необхідності внесення даних про об'єкт декларування, що перебував у користуванні суб' єкта декларування або членів його сім'ї, станом на останній день звітного періоду, а тому його варто змінити в контексті підстав притягнення до кримінальної відповідальності за декларування недостовірної інформації; 
12) слід удосконалити конструкцію неподання декларації (адміністративна відповідальність має наставати за несвоєчасне подання декларації - подання ï протягом місяця 3 дня отримання повідомлення НАЗК про факт неподання декларації, а кримінальна відповідальність - за ухилення від обов'язку подання декларації, якщо особа не подала декларацію протягом місяця після повідомлення НАЗК про факт неподання декларації; в останньому випадку варто також передбачити обов' язкове звільнення з відповідної посади за неподання декларації).

\section{Використані джерела:}

1. Рішення КСУ у справі за конституційним поданням 47 народних депутатів України щодо відповідності Конституції України (конституційності) окремих положень Закону України «Про запобігання корупщіi», Кримінального кодексу України від 27 жовтня 2020 р. №13-p/2020. Справа №1-24/2020(393/20). Сайm Конституційного суду Украӥни. URL : http://ccu.gov.ua/dokument/13-r2020. (дата звернення: 23.11.2020).

2. Кримінальний кодекс Болгарії від 1 травня 1968 р. (станом на 4 грудня 2020 р.). URL : https:/ / www.lex.bg/laws/ldoc/1589654529. (дата звернення: 23.11.2020).

3. Кримінальний кодекс Латвії від 17 червня 1998 р. (станом на 11 червня 2020 р.). URL : https:/ likumi.lv/ta/id/88966-kriminallikums. (дата звернення: 23.11.2020).

4. Кримінальний кодекс Чеської республіки від 8 січ. 2009 р. (станом на 1 жовт. 2020 р.). URL: https:/ / www.zakonyprolidi.cz/cs/2009-40. (дата звернення: 23.11.2020).

5. Кримінальний кодекс республіки Молдова від 18 квіт. 2002 р. (станом на 09.11. 2020 p.). URL : https://www.legis.md/cautare/getResults?docid=123534\&lang=ro\#. (дата звернення: 23.11.2020).

6. Кримінальний кодекс Полыщі від 6 червня 1997 р. (станом на 24 вересня 2020 р.). URL : http://isap.sejm.gov.pl/isap.nsf/download.xsp/WDU19970880553/U/D19970553Lj .pdf. (дата звернення: 23.11.2020).

7. Кривичен законик. Службен весник на Република Македонија од 23 јули 1996 г. URL : https://pretsedatel.mk/wp-content/uploads/2020/03/Krivicen-zakonik.pdf. (дата звернення: 23.11.2020).

8. Yongkang Li, Zhen Yan. (2013, May). Civil Service Property Declaration System in US and Its Enlightenments to China. In 2013 International Conference on Public Management (ICPM2013). Atlantis Press. DOI : https://doi.org/10.2991/icpm.2013.46.

9. Михайленко Д. Г. Протидія корупщійним злочинам засобами кримінального права: концептуальні основи: монографія. Одеса : Видавничий дім «Гельветика», 2017. 582 c.

10. Про внесення змін до деяких законодавчих актів України щодо забезпечення ефективності інституційного механізму запобігання корупщії: Закон України від 2 жовтня 2019 року № 140-IX /База даних «Законодавство України». ВР України. URL : https://zakon. rada.gov.ua/laws/show/140-20\#n22. (дата звернення: 23.11.2020).

11. Корупщійні схеми: їх кримінально-правова кваліфікація і досудове розслідування / за ред. М. І. Хавронюка. Київ : Москаленко О. М., 2019. 464 с.

12. Науково-практичний коментар до Закону України «Про запобігання корупщії» / Наук. ред. Хавронюк М. І. Київ : Ваіте, 2018. 472 с.

13. Дудоров О. О., Коломоєц Т. О., Кушнір С. М., Макаренков О. Л. Загально-теоретичні, адміністративно - та кримінально-правові основи концептуалізації антикорупщійної реформи в Україні: колективна монографія. Запоріжжя, 2019. 476 с. 
14. Вознюк А. А. Неконституційність декларування недостовірної інформації: аргументи та контраргументи. Реалізація державної антикорупщійної політики в міжнародному вимірі [Текст]: матеріали V Міжнар. наук.-практ. конф. (Київ, 9-10 груд. 2020 p.): у 2 ч. / [редкол.: В. В. Чернєй, С. Д. Гусарєв, С. С. Чернявський та ін.]. Київ : Нац. акад. внутр. справ, 2020. Ч. 1. C. 61-65.

15. Вознюк А. А. Декларування недостовірної інформації: актуальні проблеми досудового розслідування. Актуальні питання судової експертології, криміналістики та кримінального процесу : матеріали міжнар. наук.-практ. конф. (Київ, 5 листоп. 2019 р.) [за заг. ред. О. Г. Рувіна, Н. В. Нестор; уклад. О. І. Жеребко, А. О. Полтавський, О. В. Юдіна]. Київ : КНДІСЕ Мінюсту України, 2019. С. 109-113.

16. Черенков А. М. Розслідування декларування недостовірної інформації: автореф. дис. ... канд. юрид наук: 12.00.09. Київ, 2020.19 с.

17. Словник української мови. Академічний тлумачний словник (1970-1980). URL : http://sum.in.ua/.(дата звернення: 23.11.2020).

18. Проєкт нового Кримінального кодексу України станом на 19 жовтня 2020 p. URL : https://newcriminalcode.org.ua/upload/media/2020/10/21/kontrolnyj-proekt-kk-19-102020.pdf. (дата звернення: 23.11.2020).

19. Вознюк, А., Титко, А. (2019). Кримінально-правова модель протидії незаконному збагаченню в Україні. Вісник Пенітенциіарної асоизациї Украӥни, № 2 (8), 46-62. DOI : https: // doi. org/https://doi.org/10.34015/2523-4552.2019.2.05.

20. Стан здійснення судочинства в Україні судами кримінальної юрисдикції у 2018 р. URL : https://sud.ua/ru/news/sud-info/144078-stan-zdiysnennya-sudochinstva-sudami-krimi nalnoyi-yurisdiktsiyi-za-2018-rik-zyavilas-statistika. (дата звернення: 23.11.2020).

21. Уголовный кодекс Грузии от 22 июля 1999 г. № 2287-вс по состоянию на 19 сентября 2020 г. URL : https://www.legislationline.org/download/id/8847/file/Georgia_Criminal_Co de_am2020_ru.pdf. (дата звернення: 23.11.2020).

\section{References:}

1. Rishennia KSU u spravi za konstytutsiinym podanniam 47 narodnykh deputativ Ukrainy shchodo vidpovidnosti Konstytutsii Ukrainy (konstytutsiinosti) okremykh polozhen Zakonu Ukrainy «Pro zapobihannia koruptsii», Kryminalnoho kodeksu Ukrainy vid 27 zhovt. 2020 r., No 13-r/2020. Sprava No 1-24/2020(393/20). Sait Konstytutsiinoho sudu Ukrainy - Site of the Constitutional Court of Ukraine (2020). URL : http:/ /ccu. gov.ua/dokument/13-r2020. [in Ukrainian].

2. Kryminalnyi kodeks Bolharii (vkliucheni zminy vid 4 grudnia 2020 r.). (2020) N. p. URL : https://www.lex.bg/laws/ldoc/1589654529. [in Bulgarian].

3. Kryminalnyi kodeks Latvii vid 17 chervnia 1998 r. (zi zminamy vid 11 chervnia 2020 r.). (2020) URL : https://likumi.lv/ta/id/88966-kriminallikums. [in Latvian].

4. Kryminalnyi kodeks Cheskoi respubliky vid 8 sichnia 2009 (stanom na 01.10.2020). (2020) N. p. URL: https://www.zakonyprolidi.cz/cs/2009-40. [in Czech].

5. Kryminalnyi kodeks respubliky Moldova vid 18 kvitnia 2002 r. (stanom na 09.11.2020 r.). N. p. URL: https:// www.legis.md/cautare/getResults?doc_id=12 3534\&l ang=ro\#. [in Ukrainian].

6. Kryminalnyi kodeks Polshchi vid 6 chervnia 1997 r. (stanom na 24.09.2020 r.). (2020) N. p. URL: http://isap.sejm.gov.pl/isap.nsf/download.xsp/WDU19970880553/U/D19970553Lj. pdf. [in Polish].

7. Kryminalnyi kodeks Respubliky Makedoniia vid 23 lypnia 1996 r. (1996) N. p. URL : https: //pretsedatel.mk/wp-content/uploads/2020/03/Krivicen-zakonik.pdf. [in Macedonian]. 
8. Yongkang Li, Zhen Yan. (2013, May). Civil Service Property Declaration System in US and Its Enlightenments to China. In 2013 International Conference on Public Management (ICPM2013). Atlantis Press. DOI : https://doi.org/10.2991/icpm.2013.46.

9. Mykhailenko, D. H. (2017). Protydiia koruptsiinym zlochynam zasobamy kryminalnoho prava: kontseptualni osnovy: monohrafiia. Odesa: Vydavnychyi dim «Helvetyka». [in Ukrainian].

10. Pro vnesennia zmin do deiakykh zakonodavchykh aktiv Ukrainy shchodo zabezpechennia efektyvnosti instytutsiinoho mekhanizmu zapobihannia koruptsii: Zakon Ukrainy vid 2 zhovtnia 2019 roku № 140-IX. (2019) Baza danykh «Zakonodavstvo Ukrainy». VR Ukrainy - Database of "Legislation of Ukraine". Verkhoona Rada of Ukraine. URL : https://zakon.rada.gov.ua/laws/ show/140-20\#n22. [in Ukrainian].

11. Koruptsiini skhemy: yikh kryminalno-pravova kvalifikatsiia i dosudove rozsliduvannia (2019) M. I. Khavroniuk (Ed.). Kyiv : Moskalenko O. M. [in Ukrainian].

12. Naukovo-praktychnyi komentar do Zakonu Ukrainy «Pro zapobihannia koruptsii» (2018). Khavroniuk M. I. (Ed.). Kyiv: Vaite. [in Ukrainian].

13. Dudorov, O. O., Kolomoyecz', T. O., Kushnir, S. M., Makarenkov, O. L. (2019). Zagal’no teoretychni, administratyvno- ta kry`minal'no-pravovi osnovy konceptualizaciyi antykorup cijnoyi reformy v Ukrayini : kolekty`vna monografiya. Zaporizhya. [in Ukrainian].

14. Vozniuk, A. A. (2020). Nekonstytutsiinist deklaruvannia nedostovirnoi informatsii: arhumenty ta kontrarhumenty. Realizatsiia derzhavnoi antykoruptsiinoi polityky $v$ mizhnarodnomu vymiri: materialy of the V mizhnar. nauk.-prakt. konf. (Kyiv, 9-10 hrud. 2020 r.) - Realization of the state anti-corruption policy in the international dimension: materials of the $V$ International. scientific-practical conf. (Kyiv, December 9-10, 2020). Kyiv : Nats. akad. vnutr. sprav, 1, 61-65. [in Ukrainian].

15. Vozniuk, A. A. (2019). Deklaruvannia nedostovirnoi informatsii: aktualni problemy dosudovoho rozsliduvannia. Aktualni pytannia sudovoi ekspertolohii, kryminalistyky ta kryminalnoho protsesu: materialy mizhnar. nauk.-prakt. konf. (Kyiv, 28 lystop. 2019 r.) - Current issues of forensic expertise, criminology and criminal procedure: material intern. scientific-practical conf. (Kyiv, November 5, 2019). Kyiv : KNDISE Miniustu Ukrainy, 109-113. [in Ukrainian].

16. Cherenkov, A. M. (2020). Rozsliduvannia deklaruvannia nedostovirnoi informatsii. $E x$ tended abstract of candidate's thesis. Kyiv. [in Ukrainian].

17. Slovnyk ukrainskoi movy. Akademichnyi tlumachnyi slovnyk (1970-1980). N. p. URL : http://sum.in.ua/.[in Ukrainian].

18. Projekt novogo Kry`minal`nogo kodeksu Ukrayiny`stanom na 19 zhovtnya $2020 \mathrm{r}$. New criminalcode.org.ua. (2020) N p. URL : https://newcriminalcode.org.ua/upload/media/2020/ 10/21/kontrolnyj-proekt-kk-19-10-2020.pdf. [in Ukrainian].

19. Stan zdiisnennia sudochynstva v Ukraini sudamy kryminalnoi yurysdyktsii u 2018 r. (2018) N. p. URL : https://sud.ua/ru/news/sud-info/144078-stan-zdiysnennya-sudochin stvasudami-kriminalnoyi-yurisdiktsiyi-za-2018-rik-zyavilas-statistika. [in Ukrainian].

20. Vozniuk, A., Tytko, A. (2019). Kryminalno-pravova model protydii nezakonnomu zbahachenniu v Ukraini. Visnyk Penitentsiarnoi asotsiatsii Ukrainy - Bulletin of the Penitentiary Asso ciation of Ukraine, 2(8), 46-62. DOI : https://doi.org/https://doi.org/10.34015/2523-4552. 2019. 2.05. [in Ukrainian].

21. Ugolovnyj kodeks Gruzii ot 22 ijulja 1999 g. № 2287-vs po sostojaniju (na 19 sentjabrja 2020 g.). (2020) URL : https://www.legislationline.org/download/id/8847/file/Georgia_Criminal_ Code_am2020_ru.pdf. [in Russian]. 
Вознюк А. А.,

доктор юридических наук, профессор, заведующий лаборатории по проблемам противодействия преступности УНИ № 1 Национальной академии внутренних дел

(г. Киев, Украина)

\section{ДЕКЛАРИРОВАНИЕ НЕДОСТОВЕРНОЙ ИНФОРМАЦИИ И УМЫШЛЕННОЕ НЕПРЕДОСТАВЛЕНИЕ ДЕКЛАРАЦИИ: НОВЫЕ МОДЕЛИ ЗАПРЕЩАЮЩИХ УГОЛОВНО-ПРАВОВЫХ НОРМ}

В статье проанализированы преимущества и недостатки современных моделей оснований ответственности за декларирование недостоверной информации и умьшленное непредставление декларации - уголовно-правовой, административно-правовой и смешанной. Сделан вывод, что новые основания ответственности за декларирование недостоверной информации и непредставление декларации, а также предложения по ним, высказанные в соответствующих законопроектах, имеют недостатки, связанные с наличием основания для признания неконституционными новых запретительных уголовно-правовых норм, их санкциями, формами вины, порогом уголовной ответственности за декларирование недостоверной информации, конструкцией "непредставление декларации" и тому подобное. Сформулированы рекомендации для практики применения ст. 366-2 и 366-3 Уголовного кодекса Украины, а также предоставляются предложения по их усовершенствованию.

Ключевые слова: декларирование недостоверной информации; непредоставление декларации; декларация лица, уполномоченного на выполнение функций государства или местного самоуправления; декларация доходов; субъект декларирования; коррупщия; неконституционность.

Vozniuk A.,

Doctor of Law, Professor,

Head of the Scientific Laboratory on the Problems of Combating Crime of the Educational and Scientific Institute No 1 of the National Academy of Internal Affairs

(Kyiv, Ukraine)

\section{DECLARING INACCURATE INFORMATION AND INTENTIONAL FAILURE TO FILE A DECLARATION: NEW MODELS OF PROHIBITIVE CRIMINAL LAW PROVISIONS}

The article analyzes both advantages and disadvantages of modern models of grounds for liability for declaring inaccurate information and intentional failure to file a declaration - criminal law, administrative law and mixed.

It has been concluded that new grounds for liability for declaring inaccurate information and failure to submit a declaration, as well as proposals for them, expressed in the relevant draft laws, have the following shortcomings: 1) decision of the Constitutional Court of Ukraine on the recognition of Article 366-1 of the Criminal Code of Ukraine as unconstitutional remains unfounded; 2) the grounds for solely administrative liability for failure to submit a declaration or 
declaring unreliable information are obviously insufficient, as it is difficult to bring top corrupt officials to justice using only administrative law means in Ukraine today; 3) it was not necessary to exclude from sanctions of the corresponding articles punishment in the form of imprisonment, which is confirmed by experience of foreign countries; 4) the threshold of criminal liability for declaring inaccurate information is too high, and therefore it should be reduced; 5) criminal offenses under Articles 366-2, 366-3 of the Criminal Code of Ukraine do not belong to corruption, but it is advisable to classify them as criminal offenses, related to corruption; 6) in view of the absence in some cases of an intentional form of guilt of submission of unreliable information, it is necessary to provide for such situations a mechanism for making appropriate corrections to the already" simultaneously in the construction of the act provided for in Art. 366-2 of the Criminal Code of Ukraine, since they both indicate a deliberate form of guilt, in particular the term "knowingly" toward direct intent; 8) the words "intentionally" and "knowingly" should be removed from the constructions of the relevant acts or the responsibility for the relevant acts should be differentiated depending on the form of guilt in different articles or in different parts of one article; 9) new criminal law prohibitions should be attributed at least to minor offenses; 10) the structure of non-submission of a declaration should be improved.

Keywords: declaring unreliable information; failure to submit a declaration; declaration of the person authorized to perform functions of the state or local self-government; declaration of income; subject of declaration; corruption; unconstitutionality.

DOI: 10.33766/2524-0323.92.120-140

УДК 343.7

О. О. Дудоров, доктор юридичних наук, професор, завідувач науково-дослідної лабораторії з проблем попередження, припинення та розслідування злочинів територіальними органами Національної поліції України Луганського державного університету внутрішніх справ імені Е. О. Дідоренка (м. Севєродонецьк, Україна) e-mail: o.o.dudorov@gmail.com iDhttps://orcid.org/0000-0003-4860-0681

Р. О. Мовчан,

доктор юридичних наук, доцент, доцент кафедри конституційного, міжнародного і кримінального права Донецького національного університету імені Василя Стуса (м. Вінниця, Україна) e-mail: romanmov1984@gmail.com iDhttps://orcid.org/0000-0003-2074-8895

\section{РОЗВИТОК ЗАКОНОДАВСТВА УКРАЇНИ ПРО КРИМІНАЛЬНІ ПРАВОПОРУШЕННЯ У СФЕРІ ГОСПОДАРСЬКОЇ ДІЯЛЬНОСТІ: ПРОБЛЕМИ І ТЕНДЕНЩї}

Статтю присвячено з'ясуванню тенденщій розвитку законодавства України про відповідальніст ь за господарські кримінальні правопорушення протягом останніх

(С) Дудоров О.О.,

Мовчан Р. O., 2020 